\title{
Correlation between Stage and Histopathological Features and Clinical Outcomes in Patients with Glioma Tumors
}

\author{
Andre Lona ${ }^{1}$, Alfansuri Kadri ${ }^{2 \star}$, Irina Kemala Nasution ${ }^{2}$ \\ ${ }^{1}$ Department of Neurology, Universitas Sumatera Utara, H. Adam Malik General Hospital, Medan, Indonesia; ${ }^{2}$ Department of \\ Neurology, Universitas Sumatera Utara, H. Adam Malik General Hospital, Medan, Indonesia
}

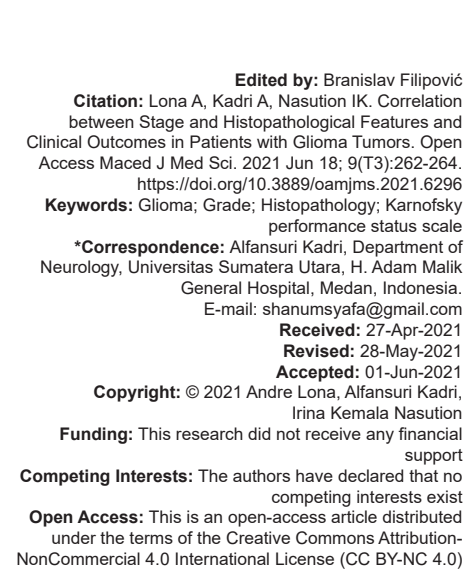

\section{Background}

Glial tumors or gliomas are tumors of supporting tissue, such as astrocytoma derived from astrocyte cells and ependymoma from epidemic cells [1]. In the United States, there are 77,000 new primary brain tumor cases each year, with 25,000 of them being malignant. The incidence rate of primary brain tumors is $22 / 100,000$ people per year [2]. In Indonesia, data collected by the Department of Neurology, RSUPN Cipto Mangunkusumo, show that the majority of primary brain tumors are astrocytoma (47\%) followed by meningioma $(26 \%)$. The mean age of patients was 48 years (18-74 years), with more females than males (55.6\% and $44.4 \%)$. At Dharmais Cancer Hospital, the incidence of brain tumors is $1 \%$ of all malignancies, with glioma (67.4\%) and meningioma (16.3\%) dominating.

The stage of malignancy of each tumor is assessed according to the WHO criteria based on the level of proliferation and mitotic activity, starting from Stage I, which has the lowest proliferation rate to stage IV, which is the most actively mitotic and is considered malignant [1]. Based on the above criteria, stage $1-$ Il is also referred to as low glioma grade (LGG) and stage III-IV as high-grade glioma (HGG) [3]. The term low-grade glioma (LGG) can be used to describe all Grade I and II gliomas according to the WHO. This terminology is useful in separating these tumors from the more aggressive HGG grades III and IV, according to the WHO. The term LGG is usually used to refer to the WHO Grade II tumors, such as astrocytoma, oligodendroglioma, and oligoastrocytoma [4], while the term HGG is usually used to refer to Grade III and IV tumors consisting of anaplastic astrocytoma, anaplastic oligodendroglioma, anaplastic oligoastrocytoma, and anaplastic ependymoma. Often found in the eloquent area, namely the motor, language, visuospatial, and memory function areas. Survival in 5 years and progression-free survival are $58-72 \%$ and $37-55 \%$. LGG patients can survive up to 20 years, but the tumor continues to grow and can progress to HGG, causing neurological deficits and death [5], [6], [7].

This research aimed to determine whether there is a relationship between clinical outcome using the Karnofsky Performance Status (KPS) scale for the assessment of tumor patient's functional status to histological features and staging of intracranial tumor patients [8]. 


\section{Methods}

This study was an observational analytic study with a retrospective approach at RSUP H. Adam Malik Medan from September 2019 to September 2020. The study population was glioma patients. The research sample was 36 subjects taken consecutively. The independent variables of the study were stage and histopathological description, while the dependent variable of the study was the KPS Scale. Statistical analysis with the help of a computer program Windows SPSS (Statistical Product and Science Service) version 22.0, using the Gamma test.

\section{Results}

Glioma patients who underwent treatment at RSUP Haji Adam Malik Medan in the period September 2019 to September 2020, 36 study subjects met the inclusion and exclusion criteria, so they were included in this study.

Based on the demographic characteristics of research subjects, it was found that age had a mean of $38.11 \pm 13.86$ years. Most of the research subjects were male, amounting to 20 subjects $(55.6 \%)$, while women were 16 subjects (44.6\%). The most common type of glioma tumor was anaplastic astrocytoma, amounting to 8 subjects $(22.2 \%)$. The highest tumor stage was a HGG, amounting to 19 subjects (52.8\%) and the most histopathological features based on the WHO criteria were the WHO grade 3 totaling 13 subjects (36.1\%). The most KPS Scale is 80-100 with 19 subjects $(52.8 \%)$ (Table 1).

Table 1: Demographic characteristics of research subjects

\begin{tabular}{|c|c|c|c|}
\hline Variable & Average & $\mathrm{n}$ & $\%$ \\
\hline Age (years), mean \pm SD & $38.11 \pm 13.86$ & & \\
\hline \multicolumn{4}{|l|}{ Gender } \\
\hline Male & & 20 & 55.6 \\
\hline Women & & 16 & 44.4 \\
\hline \multicolumn{4}{|l|}{ Types of tumors } \\
\hline Ependymoma & & 1 & 2.8 \\
\hline Anaplastic astrocytoma & & 8 & 22.2 \\
\hline Oligodendroglioma & & 6 & 16.7 \\
\hline Pilocytic astrocytoma & & 6 & 16.7 \\
\hline Diffuse astrocytoma & & 4 & 11.1 \\
\hline Anaplastic oligodendroglioma & & 5 & 13.9 \\
\hline Glioblastoma & & 6 & 16.7 \\
\hline \multicolumn{4}{|l|}{ Stadium } \\
\hline Low grade & & 17 & 47.2 \\
\hline High grade & & 19 & 52.8 \\
\hline \multicolumn{4}{|l|}{ Histopathology } \\
\hline WHO Grade 1 & & 6 & 16.7 \\
\hline WHO Grade 2 & & 11 & 30.6 \\
\hline WHO Grade 3 & & 13 & 36.1 \\
\hline WHO Grade 4 & & 6 & 16.7 \\
\hline \multicolumn{4}{|l|}{ Karnofsky performance status scale } \\
\hline $0-79$ & & 17 & 47.2 \\
\hline $80-100$ & & 19 & 52.8 \\
\hline
\end{tabular}

The mean age of the subjects in this study is relevant to a previous study by Sanai et al. [9], which reported that the median age of glioma tumor patients was $45(18-81)$ years. The most gender in male subjects was 20 subjects $(55.6 \%)$, this result is relevant to a study conducted by Chen et al. [10] which reported in a study of IDH1 mutations and seizures in patients with glioma, of 712 subjects there were 400 subjects $(56,1 \%)$ are male. The highest KPS score was 80-100, totaling 19 subjects $(52.8 \%)$, this result is relevant to a study conducted by Kim et al. [11] conducted by You et al. [12], who reported that KPS scores $>80$ in LGG patients accounted for $88 \%$ of their study subjects.

\section{Discussion}

- Relationship between stage and clinical outcome in glioma tumor patients

In this study, it was shown that the LGG stage, which had a KPS score of $80-100$, was 11 subjects $(64.7 \%)$ and six subjects $(35.3 \%)$ had a KPS score of 0-79, while the HGG stage with a KPS score of 80-100 was six subjects $(31.6 \%)$ and those with a KPS value of $0-79$ were 13 subjects $(68.4 \%)$. Based on the gamma test, it was found that there was a positive and significant correlation between the glioma stage and the KPS with moderate correlation strength $(p=0.036 ; r=0.598)$ (Table 2). The results of this study are relevant to the Statistical Report of the Central Brain Tumor Registry of the United States in 2011, which reports that the relative survival rate for low-grade astrocytoma for 2 years is $60 \% ; 48 \%$ for 5 years, and $39 \%$ for 10 years. The relative survival rate for low-grade oligodendroglioma for 2 years was $90 \%, 5$ years was $79 \%, 10$ years was $64 \%$, and concluded that the life expectancy of LGG is longer than HGG [1].

Table 2: The relationship between stage and clinical outcome in glioma tumor patients

\begin{tabular}{lllll}
\hline Stadium & \multicolumn{2}{l}{ KPS $(\mathrm{n} / \%)$} & $\mathrm{r}$ & $\mathrm{p}$ \\
\cline { 2 - 3 } & Score $80-100$ & Score $0-79$ & & 0,598 \\
\hline Low grade & $11(64.7)$ & $6(35.3)$ & 0,036 & \\
High grade & $6(31.6)$ & $13(68.4)$ & \\
Total & $17(47.2)$ & $19(52.8)$ &
\end{tabular}

- Relationship between histopathology and clinical outcomes in patients with glioma tumors

In this study, it shows that the histopathological picture with the WHO Grade 1,, which has a KPS value of $80-100$, is five subjects $(83.3 \%)$ and those with a KPS value of 0-79 are one subject (16.7\%). The WHO Grade 2, which had a KPS score of 80-100, amounted to 6 subjects $(54.5 \%)$ and those with a KPS value of $0-79$ were five subjects (54.5\%). The WHO Grade 3, which had a KPS score of 80-100, amounted to 4 subjects $(30.8 \%)$ and those with a KPS value of 0-79 were nine subjects (69.2\%). The WHO Grade 4, which had a KPS score of $80-100$, amounted to 2 subjects (33.3\%) and those with a KPS value of 0-79 were four subjects $(66.7 \%)$. Based on the gamma test, it was found that there was a positive and significant correlation between 
the histopathological picture and the KPS with moderate correlation strength $(p=0.024 ; r=0.508)$ (Table 3$)$. The results of this study are relevant to the research conducted by Lapointe et al. [13], which stated that the higher the grade of glioma, the worse the prognostic value. Another relevant study conducted by Krisnan et al. reported that there was a significant relationship between stage and histopathologic features on survival of patients with glioma $(p<0.005)$ and high life expectancy in study subjects who had a kps score $>80$ (HR 2.2061) [14].

Table 3: The relationship between histopathological features and clinical outcomes in patients with glioma tumors

\begin{tabular}{lllll}
\hline Stadium & KPS $(\mathrm{n} / \%)$ & $\mathrm{r}$ & $\mathrm{p}$ \\
\cline { 2 - 3 } & Score 80-100 & Score 0-79 & & \\
\hline WHO Grade 1 & $5(83.3)$ & $1(16.7)$ & 0.508 & $0.024^{*}$ \\
WHO Grade 2 & $6(54.5)$ & $5(45.5)$ & & \\
WHO Grade 3 & $4(30.8)$ & $9(69.2)$ & & \\
WHO Grade 4 & $2(33.3)$ & $4(66.7)$ & & \\
Total & $17(47.2)$ & $19(52.8)$ & & \\
\hline *Using Gamma test. & & & &
\end{tabular}

Determining the response of intracranial tumors to treatment remains a major challenge in the field of neuro-oncology. KPS Scale is a widely used method for assessing the functional status of a patient. This scale was introduced by Karnofsky and Burchenal in 1949 in an article originally published as part of the book "Evaluation of Chemotherapeutic agents" edited by MacLeod [1]. The KPS Scale is a which is widely used to assess the functional status of a patient. KPS Scale describes the functional status of patients in 11 correlation scales with percentage values ranging from $100 \%$ (no evidence of disease or symptoms) to $0 \%$ (death) [1]. One study using KPS as a tool to assess clinical outcomes is a study conducted by Ritarwan et al. in 2018 in Medan in a study of the correlation between leukocyte subtypes and neutrophil-lymphocyte ratio with clinical outcomes in brain metastatic patients.

\section{Conclusion}

Determination of the clinical outcome in intracranial tumor patients, especially gliomas, remains a major challenge in the field of neuro-oncology. KPS Scale is a method that can be used to assess clinical outcomes in patients with intracranial tumors. In this study, there was a significant correlation between stage and histopathological features with KPS with moderate correlation strength.

\section{References}

1. Anindita T, dan Wiratman W, editors. Buku Ajar Neurologi. Jakarta: Fakultas Kedokteran Universitas Indonesia; 2017.
2. Park S, Won J, Kim S, Lee Y, Park C, Kim S, et al. Molecular testing of brain tumour. J Pathol Transl Med 2017;51(3):205-23 PMid:28535583

3. Shree NV, Kumar TN. Identification and classification of brain tumour MRI images with feature extraction using DWT and probabilistic neural network. Brain Inform. 2018;5(1):23-30. https://doi.org/10.1007/s40708-017-0075-5

PMid:29313301

4. Derek RJ, Jaeckle KA. Low-grade glioma and oligodendroma in adulthood. In: Neuro-oncology. $1^{\text {st }}$ ed. New Jersey: Blackwell Publishing Ltd.; 2012. p. 76-85.

5. Kalkanis SN, Rosenblum ML. Malignant glioma. Dalam: Ogden AT, Bruce JN. Pineal Region Tumors. Dalam: Bernstein $M$, Berger MS. Neuro-Oncology the Essentials. $2^{\text {nd }}$ ed. New York: Thieme; 2008. p. 254-65. https://doi.org/10.1055/b-0034-63653

6. Soffietti R, Baumert BG, Bello L, von Deimling $A$, Duffau $\mathrm{H}$, Frénay $M$, et al. Guidelines on the management of low-grade gliomas: EANO task force report. Eur Assoc Neurol. 2010;17(9):1124-33. https://doi. org/10.1111/j.1468-1331.2010.03151.x PMid:20718851

7. Diwanji TP, Engleman A, Snider JW, Mohindra P. Epidemiology, diagnosis, andoptimal management of glioma in adolescents and young adults. Adolesc Health Med Ther. 2017;8:99-113. https://doi.org/10.2147/ahmt.s53391 PMid:28989289

8. Aninditha T, Andriani R, dan Mauleka RG. Kelompok Stud Neuro-Onkologi. Buku Ajar Neuroonkologi. $1^{\text {st }}$ ed. Jakarta: Perhimpunan Dokter Spesialis Saraf Indonesia; 2019. p. 1-209. https://doi.org/10.52386/neurona.v37i4.174

9. Sanai N, Martino J, Berger MS. Morbidity profile following aggressive resection of parietal lobe gliomas. J Neurosurg. 2012;116(6):1182-6. https://doi.org/10.3171/2012.2.jns111228

10. Chen H, Judkins J, Thomas C, Golfinos JG, Lein $P$, Chetkovich DM. Mutant IDH1 and seizures in patients with glioma. Neurology. 2017;88(19):1805-13. https://doi. org/10.1212/wnl.0000000000003911 PMid:28404805

11. Kim YH, Park CK, Kim TM, Choi SH, Kim YJ, Choi BS, et al. Seizures during the management of high-grade gliomas: Clinical relevance to disease progression. J Neurooncol. 2013;113(1):101-9. https://doi.org/10.1007/s11060-013-1094-6 PMid:23459994

12. You G, Sha ZY, Yan W, Zhang W, Wang YZ, Li SW, et al. Seizure characteristics and outcomes in 508 resection of lowgrade gliomas: A clinicopathological study. Neurooncology. 2012;14(2):230-41.

PMid:22187341

13. Lapointe S, Perry A, Butowski NA. Primary brain tumours in adults. 2018;392(10145):432-46. https://doi.org/10.1016/ s0140-6736(18)30990-5 PMid:30060998

14. Krishnan SS, Muthiah S, Rao S, Salem SS, Madabhushi VC, Mahadevan A. Mindbomb homolog-1 index in the prognosis of high-grade glioma and its clinicopathological correlation. J Neurosci Rural Pract. 2019;10(2):185-93. https://doi. org/10.4103/jnrp.jnrp_374_18 PMid:31001003

15. Ritarwan K, Nasution IK, Erwin I. Correlation of leukocyte subtypes, neutrohyl lymphocyte ratio, and functional outcome in brain metastasis. Open Access Maced J Med Sci. 2018;6(12):2333-6. https://doi.org/10.3889/oamjms.2018.477 PMid:30607186 